\title{
Comparative effects of full-tree and tree-length shelterwood harvesting on residual tree damage and coarse woody debris volume in the Great Lakes - St. Lawrence forest
}

\author{
by Trevor A. Jones ${ }^{1}$ and Scott McPherson²
}

\begin{abstract}
Residual stand damage and coarse woody debris loads were evaluated in 15 hardwood and white pine uniform shelterwood harvest blocks, in the Great Lakes - St. Lawrence Forest Region, using tree-length (TL) and full-tree (FT) harvesting techniques. Stand-level damage rates to residual stems in both the TL and FT harvest operations were below Ontario's allowable "major" damage limits of $15 \%$ to all residual trees and $10 \%$ to acceptable growing stock (AGS) trees. No significant differences in damage rates were observed between the TL and FT harvest systems and were comparable to past assessments in TL and FT harvested blocks. Despite efforts to increase utilization of material from these study sites, no significant differences were observed in coarse woody debris (CWD) volume or the distribution of that volume across decay classes.
\end{abstract}

Key words: full-tree harvesting, hardwoods, white pine, shelterwood silviculture, coarse woody debris, logging damage

\section{RÉSUMÉ}

On a évalué les blessures aux arbres résiduels et la quantité de débris ligneux grossiers dans 15 blocs de coupes progressives uniformes de feuillus et de pin blanc situés dans la région forestière des Grands Lacs et du Saint-Laurent utilisant les techniques de récolte par arbres en longueur (TL) et par arbres entiers (AE). Les taux de blessures aux arbres résiduels dans lensemble du peuplement, tant dans les opérations de TL que d'AE, se situaient sous les limites permises en Ontario pour les blessures « importantes » soit $15 \%$ pour tous les arbres résiduels et de $10 \%$ pour les arbres formant le stock sur pied acceptable (SPA). Aucune différence significative dans les taux de blessures na été observée entre les systèmes de récolte par TL et par $\mathrm{AE}$ et ces taux étaient comparables aux évaluations antérieures pour des blocs récoltes par TL et par AE. Malgré des efforts pour accroître l'utilisation de la matière ligneuse tirée de ces sites détude, aucune différence significative na été observée dans le volume de débris ligneux grossiers et dans sa répartition parmi les classes de décomposition.

Mots clés : récolte par arbres entiers, pin blanc, sylviculture par coupes progressives, débris ligneux grossiers, blessure d'exploitation

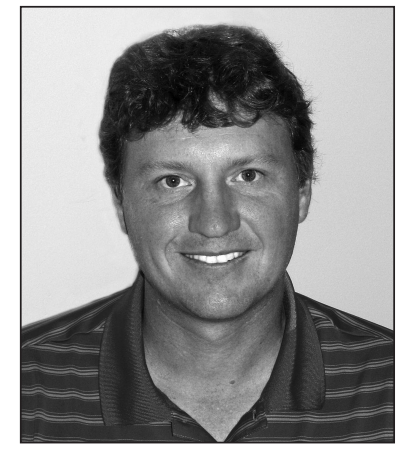

Trevor A. Jones

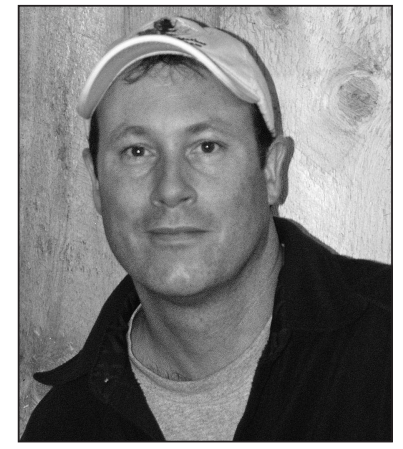

Scott McPherson

\section{Introduction}

The Great Lakes - St Lawrence (GLSL) forests of central Ontario have had a long history of management and manipulation. Past anthropogenic activities and natural disturbances have significantly influenced the species composition, stand structural attributes, and health of the current forest. Prior to the development and enforcement of the Crown Forest Sustainability Act (Statutes of Ontario 1995) many of the forests in southern and central Ontario were selectively harvested, with a preference for the biggest and best trees of the desired species. More often than not, the remaining forest was severely damaged by logging operations, stocked with unhealthy trees and left to regenerate to species that were less

\footnotetext{
${ }^{1}$ Ontario Ministry of Natural Resources, Ontario Forest Research Institute, 1235 Queen Street East, Sault Ste Marie, Ontario P6A 2E5. EMail: trevor.jones2@ontario.ca

${ }^{2}$ Ontario Ministry of Natural Resources, Southern Science and Information Section, 3301 Trout Lake Road, North Bay, Ontario P1A 4L7. E-mail: scott.mcpherson@ontario.ca
} 
well suited to the sites they occupied. In the 1980s and 90s, many stands were harvested using the selection silviculture system because it was viewed as the most ecologically sustainable solution for managing hardwood forests even when site productivity, species composition, and forest structure were not suited to this approach. The prevalence of small canopy gap disturbances associated with selection harvesting led to a persistence of shade-tolerant hardwoods within the GLSL region (Jackson et al. 2000). The continued loss of mid-tolerant species, such as yellow birch (Betula allegheniensis Britt.), white pine (Pinus strobus L.), and red oak (Quercus rubra L.), resulted in decreased species diversity (Schwartz et al. 2005, Neuendorff et al. 2007, Webster and Jensen 2007).

The net result was that large areas of the forest were degraded and in need of species rejuvenation and quality improvement. The current tool for regenerating mid-tolerant species and restoring damaged stands to healthier and more productive forest is the shelterwood silviculture system. However, regenerating mid-tolerant species in these stands is challenging, often requiring heavy investment in site preparation, planting, and repeated tending treatments. To achieve the desired outcome, both careful logging and post-harvest silviculture activities are usually required. Even with these large investments, successful regeneration of some species, red oak for example, is often not very successful.

From an economic perspective, damage to residual trees during the harvest operation or subsequent silviculture treatments is a major concern because it can lead to loss of product volume and reduced value (Rice 1994, Vasiliauskas 2001). From an ecological perspective, damage to residuals can increase mortality rates (Caspersen 2006) as well as reduce tree- (Jones and Thomas 2004) and stand-level growth rates if tree health is compromised as a result of the harvest (Bedard and Majcen 2001, Forget et al. 2007). Cline et al. (1991) and Fajvan et al. (2002) indicated that logging damage is most common on boles, with less injury to roots and crowns. In a study of whole-tree harvesting by Kelly (1983), up to $80 \%$ of the damage occurred on the stems. This damage is the result of trees being extracted from where they are felled and traffic on skid trails. Crown damage can be controlled with careful felling practices and root damage can be minimized by limiting trail coverage and soil compaction and rutting.

To offset the cost of achieving silvicultural and ecological objectives in shelterwoods, some combination of three economic drivers must occur during harvest. First, the harvest must recover and markets must be found for large quantities of small-diameter and low-quality material. Second, sufficient volume of higher-value, defect-free material is needed to increase the value per unit volume recovered from the harvest block. Third, increased efficiencies in per-unit volume harvest and transport costs must offset the fixed costs of fibre acquisition. One way to increase volume per unit area is to increase the utilization of material recovered. Full-tree harvesting both increases recovery of material and potentially reduces harvest cost per unit area. In addition, it may reduce the cost of site preparation through slash removal and substrate scarification via skidding during harvesting. Full-tree harvesting, during the limbing phase of operations, also offers a safer and more productive work environment for processing tree tops; these are important considerations for controlling costs and for worker safety. However, in Ontario's current sil- viculture guidelines for shelterwood (and selection) management systems, full-tree harvesting is "not recommended" due to potential for damage when skidding tops and limbs (OMNR 1998a,b). Skidding of large limbed trees could (1) damage more residual trees, (2) disturb a greater proportion of the advanced regeneration both within and beyond skid trails, and (3) increase disturbance of the soil surface. Moreover, concerns have been expressed about the effect of fulltree logging on productivity of the stand for future harvests and coarse woody debris (CWD) loads, and the effect of reduced CWD on wildlife habitat and species diversity (Berch et al. 2011, Puddister et al. 2011).

To address some of these concerns, several provincial, national, and international studies have been initiated to evaluate the effects of full-tree harvesting and increased utilization harvests on stand productivity in clearcut systems (Hornbeck et al. 1990, Tenhagen et al. 1996, Morris and Duckert 1999, Duckert and Morris 2008, Morris 2009, Fleming 2011). In addition, the Ontario Ministry of Natural Resources (OMNR) and partners have begun a series of harvesting experiments in the GLSL forest to investigate the effects and benefits of full-tree logging. The intent is to document the effects of increased utilization harvests (including full-tree harvests) on soil nutrient availability, substrate disturbance, woody debris loads, as well as damage to advanced regeneration. These studies provide intensive plot-based measures of harvest effects at the stand level but do not capture variation among harvest blocks. To quantify harvest block-level effects, more extensive cruising data and comparisons among multiple blocks are required. Since 2004, surveys of damage to residual trees have been carried out on a relatively small scale on two central Ontario management units as part of required monitoring for full-tree harvesting trial areas, referred to as exceptions monitoring. However, to be useful, these surveys need to cover a broader scope of conditions and results compared to those from tree-length harvesting.

The study reported here was designed to complement the data collected as part of previous exceptions monitoring in full-tree (FT) and tree-length (TL) logging operations between 2004 and 2010. We evaluate two uniform shelterwood harvest block-level questions as follows: Relative to TL harvesting, (1) does FT harvesting increase damage to residual trees, and (2) does FT harvesting deplete CWD?

\section{Methods \\ Study sites}

We evaluated residual tree damage and CWD volume on 11 different hardwood and four white pine uniform shelterwood harvest blocks from three Sustainable Forest Licences (SFL) in the GLSL forest region of Central Ontario (Fig. 1). Dominant species in the region include sugar maple (Acer saccharum Marsh.), red maple (Acer rubrum L.), yellow birch, eastern white pine, red oak, white birch (Betula papyrifera Marsh.), white spruce (Picea glauca [Moench] Voss), and red pine (Pinus resinosa Ait.), as well as largetooth (Populus grandidentata Michx.) and trembling (Populus tremuloides Michx.) aspen.

Stands included in the study were all harvested at the regeneration cut stage of the shelterwood silvicultural system. All harvest blocks were prescribed as uniform shelterwood regeneration cut due to stand structure, species composition 


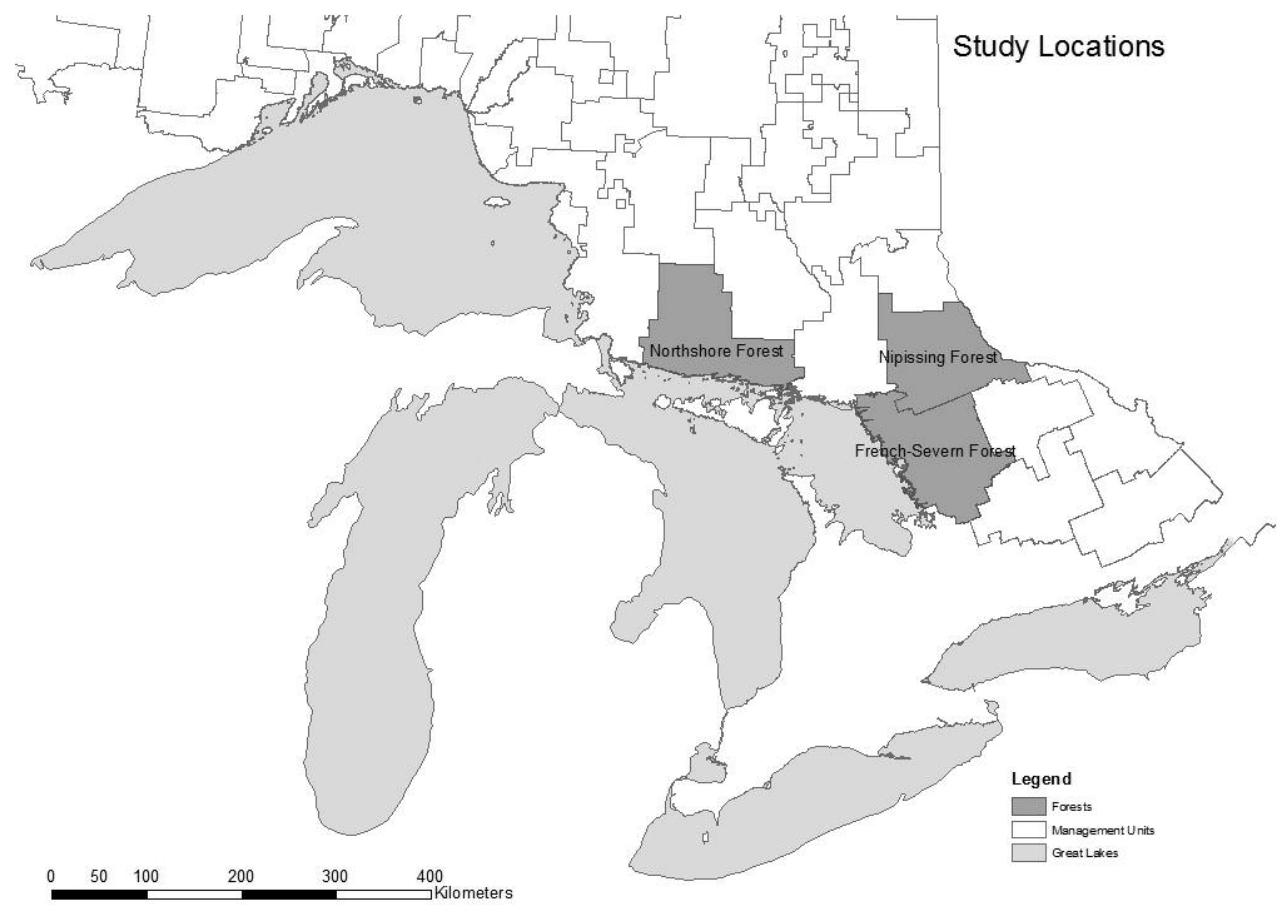

Fig. 1. Locations of the Northshore, Nipissing, and French-Severn Forests within the Great Lakes - St. Lawrence Forest Region of Ontario.

and health criteria within the SFL management plans. All bocks were harvested prior to the inception of this study; however, no post-harvest site preparation or tending treatments had been undertaken in the harvest blocks and the harvests had all occurred after 2009. In addition, all of the sites were harvested using mechanized logging with feller bunchers and grapple skidders. The number, size and composition of the harvest blocks used in the study were constrained by the availability of harvest blocks that met the criteria for inclusion within the GLSL forest region of central Ontario. The decision to harvest as FT in five of the 15 blocks harvested was not based on pre-harvest forests structure or tree spacing but rather based on the need to operationally test the feasibility of FT harvesting on "typical" uniform shelterwood regeneration cuts. In total, 10 sites (harvest blocks) were chosen from Nipissing Forest (NP), three from Northshore Forest (NS) and two from French-Severn Forest (FS). Of those harvest blocks, two white pine and three hardwood harvest blocks were harvested using FT harvesting methods.

\section{Sampling design}

Each harvest block was sampled systematically using a predefined grid of sample points. To accomplish this, geographic information system (GIS) data and harvest block records were obtained from the SFLs and a 75-m to $150-\mathrm{m}$ grid was established uniformly over the entire harvest area. Grid size was determined based on the size of the harvest block. Harvest blocks under 50 ha were sampled at $75 \mathrm{~m}$, blocks between
50 ha and 75 ha were sampled at 100-m spacing and blocks over 75 ha were sampled at $150-\mathrm{m}$ spacing. Our goal was to obtain between 20 and 50 plots per harvest area to fairly represent the average stand condition across the entire area. During field sampling, plots were excluded if they occurred within $10 \mathrm{~m}$ of roads, landings, or areas of concern (AOC) and harvest boundaries.

\section{Field measurements}

To assess residual basal area, a basal area factor 2 prism (BAF 2) sweep was conducted at each plot centre. Each tree identified as within the prism plot was evaluated for pre-harvest health status, ignoring any wounds that occurred during recent harvest operations. Trees were determined to be healthy and acceptable growing stock (AGS) or unhealthy and unacceptable growing stock (UGS) using criteria described in Ontario's tree marking guide (OMNR 2004). Trees were also evaluated visually for logging damage to the bole, crown, and roots. Trees with greater than $20 \%$ to $30 \%$ projected losses in crown or root volumes, due to breakage or shearing, as well as any trees that were snapped off or tipping up, was also considered to have major damage. Trees with bole damage greater than $900 \mathrm{~cm}^{2}$ were assessed as having major wounds; those with less than $900 \mathrm{~cm}^{2}$ bole damage were considered to have minor wounds. Furthermore, any tree with a wound greater in width than the diameter of the tree was considered to have major damage. These definitions of major damage are a simplified yet slightly more stringent 
version of the major damage criteria described in Ontario's silviculture guides (OMNR 1998a,b), providing a conservative estimate of whether these harvesting methods result in stands that meet the standards for Crown land. We chose these more stringent criteria because setting a fixed wound size for all trees was easier to determine on a consistent basis than the methods described in the silviculture guides (OMNR 1998a,b), and could be rapidly assessed. The lower criteria for crown and root damage were more biologically meaningful with respect to potential for reduced growth and future health risk.

At each plot centre, two 20-m perpendicular CWD transects were established; one in a North-South direction and another in an East-West direction. Diameters of CWD that intersected the transects were measured at the point of intersection. Each piece of CWD was identified to species based on residual bark and/or branch morphology. Species of highly decayed CWD were recorded as unknown. Each piece of CWD was also assigned one of five decay classes using criteria first described by Maser et al. (1979). The volume of CWD was calculated at the harvest block level using the line intersect method described in Marshall et al. (2000).

\section{Historic data}

In addition to the residual stem damage data collected as part of this study, data were compiled from an additional 34 recent FT harvest blocks as well as 25 TL harvest blocks. These data were collected by different individuals from three different SFLs. The sample intensity and design were non-standard within and between treatments and harvest blocks and as a result the data were adequate for validation of the current study results but could not be added to the current studies data for direct comparison. For these historic data sets, the total residual basal area, proportion of basal area (BA) with major damage, and the proportion of major damage to AGS trees were recorded. Criteria for major damage were those set out in the provincial silviculture guides, i.e., bole wounds greater than $1000 \mathrm{~cm}^{2}$ on trees greater than $31 \mathrm{~cm}$ in diameter and any wound greater than or equal to the square of the tree's diameter for trees under $31 \mathrm{~cm}$ diameter at breast height $(\mathrm{DBH})$ were considered major. Crown damage $>33 \%$ and root damage $>25 \%$ were also considered major (OMNR 1998a,b).

\section{Data analyses}

The total tree damage rate (\%) was calculated as the total basal area of trees damaged in the harvest block divided by the total basal area of trees sampled in the block. Similarly, the percent of basal area with major damage was calculated as the basal area of trees with major damage divided by total basal area of trees sampled. The percent of AGS stems with major damage was also calculated as the proportion of AGS basal area that showed evidence of major damage. An analysis of variance (SAS v9.2) was used to test for differences in harvest block-level residual basal areas, volumes, and damage rates as well as differences in CWD volumes between the FT and TL harvest treatments. The experimental unit for analysis was the harvest block, which resulted in a total sample size of 15 . To test for differences in CWD volume by decay class, a two-way ANOVA was employed. A separate ANOVA was run on the historic data sets due to the differences in criteria used to assess damage and the large differences in sample size between the two data sources. No direct statistical comparison was made between the current and historic datasets.

\section{Results}

\section{Residual stand structure}

In total we sampled 510 plots across 15 harvest blocks in three different forests. Plot-level variability in residual basal area within a harvest block was high, ranging from $2 \mathrm{~m}^{2} \mathrm{ha}^{-1}$ to 32 $\mathrm{m}^{2} \mathrm{ha}^{-1}$ (Fig. 2). Average residual basal areas were also highly variable, with a nearly two fold difference among harvest blocks, ranging from $8.4 \mathrm{~m}^{2} \mathrm{ha}^{-1}$ to $14.7 \mathrm{~m}^{2} \mathrm{ha}^{-1}$ (Table 1). Because of this variability, no significant difference $(P=$ 0.294) in average block-level residual BA was apparent between the FT and TL treatments (Table 1).

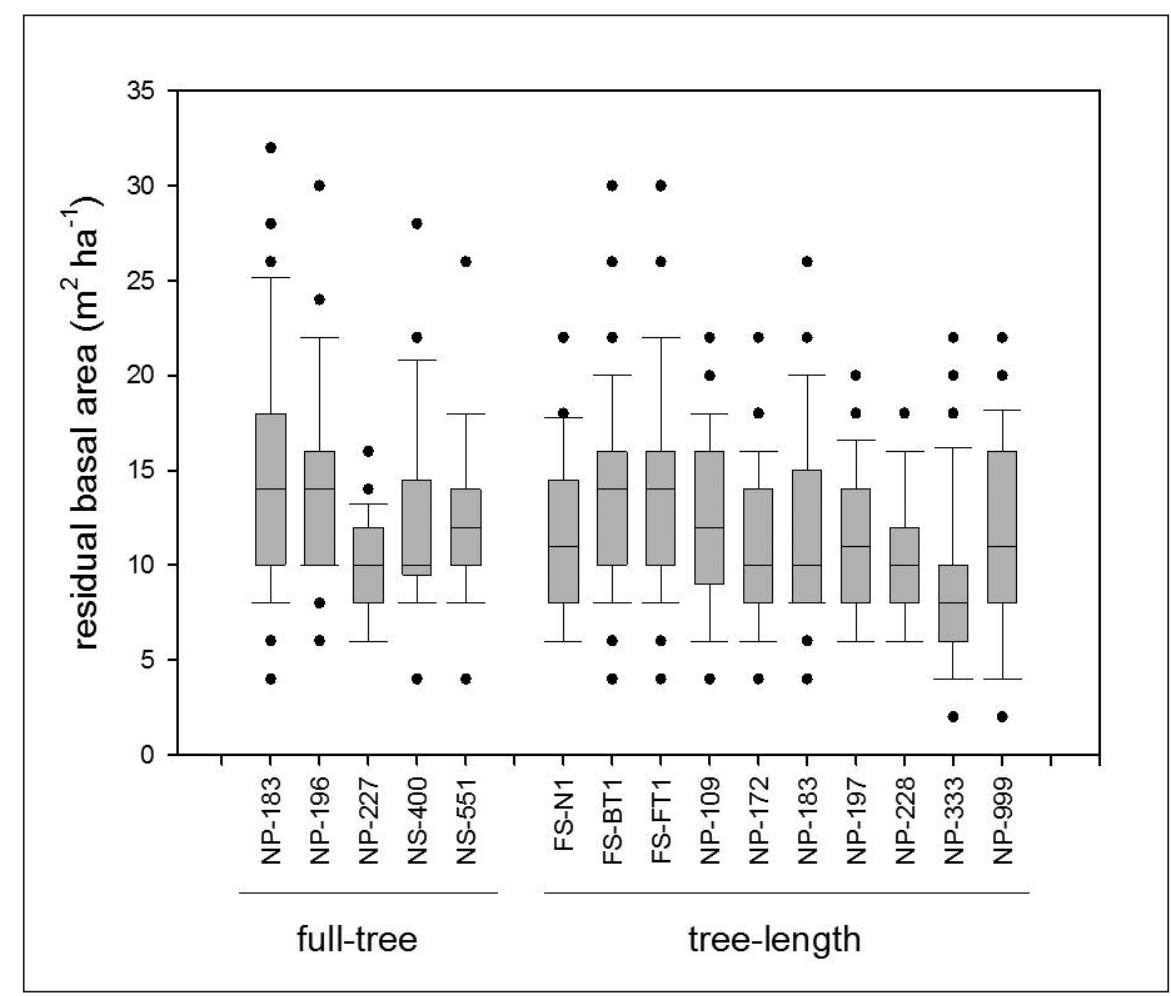

Fig. 2. Plot-level residual basal areas distribution within the full-tree and tree-length harvest blocks in central Ontario. Boxes represent the $25^{\text {th }}$ and $75^{\text {th }}$ percentile; bars represent the $10^{\text {th }}$ and $90^{\text {th }}$ percentile. Plots below the $10^{\text {th }}$ percentile and above the $90^{\text {th }}$ percentile of residual basal area are represented by dots. 
Table 1. Post-harvest residual damage and coarse woody debris (CWD) volumes from recent full-tree and tree-length harvests in central Ontario forests

\begin{tabular}{|c|c|c|c|c|c|c|c|c|c|}
\hline \multirow{2}{*}{$\begin{array}{l}\text { Harvest type/ } \\
\text { Block name }\end{array}$} & \multirow[b]{2}{*}{$\mathrm{SFL}^{\mathrm{a}}$} & \multirow[b]{2}{*}{ Forest Type } & \multirow{2}{*}{$\begin{array}{l}\text { Number } \\
\text { of Plots }\end{array}$} & \multirow{2}{*}{$\begin{array}{l}\text { Total } \mathbf{B A}^{\mathbf{b}} \\
\left(\mathrm{m}^{2} \mathbf{h a}^{-1}\right)\end{array}$} & \multirow{2}{*}{$\begin{array}{c}\text { Total AGS } \\
\text { BA }\left(\mathbf{m}^{2} \mathbf{h a}^{-1}\right)\end{array}$} & \multicolumn{3}{|c|}{ Damage (\% BA) } & \multirow{2}{*}{$\begin{array}{c}\text { CWD } \\
\text { volume } \\
\left(\mathrm{m}^{3} \mathbf{h a}^{-1}\right)\end{array}$} \\
\hline & & & & & & Total & Major all & Major AGS ${ }^{c}$ & \\
\hline \multicolumn{10}{|l|}{ Full-tree } \\
\hline NP-183 & Nipissing & Hardwood & 43 & 14.7 & 8.7 & 7.5 & 2.5 & 4.3 & 56.4 \\
\hline NP-196 & Nipissing & Hardwood & 49 & 14.2 & 7.9 & 9.7 & 6.9 & 12.4 & 50.3 \\
\hline NP-227 & Nipissing & Hardwood & 23 & 9.7 & 5.7 & 17.9 & 6.3 & 10.6 & 47.4 \\
\hline NS-400 & Northshore & White pine & 22 & 12.4 & 10.8 & 8.1 & 2.9 & 3.4 & 63.3 \\
\hline NS-551 & Northshore & White pine & 19 & 12.0 & 9.9 & 12.2 & 2.6 & 3.4 & 68.4 \\
\hline Mean \pm SE & & & & $12.6 \pm 0.9$ & $8.6 \pm 0.9$ & $11.1 \pm 1.9$ & $4.3 \pm 1.0$ & $6.8 \pm 2.0$ & $57.2 \pm 3.9$ \\
\hline \multicolumn{10}{|l|}{ Tree-length } \\
\hline FS-N1 & French-Severı & nHardwood & 30 & 11.5 & 9.6 & 9.8 & 3.4 & 4.1 & 50.9 \\
\hline FS-BT1 & French-Severı & nHardwood & 11 & 12.9 & 10.9 & 8.5 & 2.8 & 3.3 & 67.8 \\
\hline FS-FT1 & French-Sever1 & nHardwood & 48 & 14.3 & 12.7 & 5.6 & 3.2 & 3.5 & 90.8 \\
\hline NP-109 & Nipissing & Hardwood & 37 & 12.4 & 6.8 & 20.0 & 9.1 & 16.8 & 60.2 \\
\hline NP-172 & Nipissing & Hardwood & 31 & 10.0 & 5.0 & 20.6 & 8.3 & 16.9 & 52.7 \\
\hline NP-183 & Nipissing & Hardwood & 49 & 12.2 & 6.7 & 8.0 & 4.3 & 8.0 & 38.7 \\
\hline NP-197 & Nipissing & Hardwood & 30 & 11.8 & 9.7 & 11.9 & 9.6 & 11.7 & 36.3 \\
\hline NP-228 & Nipissing & Hardwood & 36 & 10.6 & 4.0 & 34.0 & 6.8 & 18.1 & 68.4 \\
\hline NP-333 & Nipissing & White pine & 34 & 8.4 & 8.2 & 13.4 & 4.9 & 5.0 & 41.9 \\
\hline NP-999 & Nipissing & White pine & 48 & 11.5 & 11.1 & 13.4 & 9.3 & 9.8 & 46.2 \\
\hline Mean \pm SE & & & & $11.6 \pm 0.5$ & $8.5 \pm 0.9$ & $14.5 \pm 2.6$ & $6.2 \pm 0.9$ & $9.7 \pm 1.9$ & $55.4 \pm 5.3$ \\
\hline ANOVA & & & & $\begin{array}{c}F=1.20 \\
P=0.294 \\
n=15\end{array}$ & $\begin{array}{c}F=0.01 \\
P=0.927 \\
n=15\end{array}$ & $\begin{array}{c}F=0.71 \\
P=0.416 \\
n=15\end{array}$ & $\begin{array}{c}F=1.92 \\
P=0.190 \\
n=15\end{array}$ & $\begin{array}{c}F=0.98 \\
P=0.341 \\
n=15\end{array}$ & $\begin{array}{c}F=0.05 \\
P=0.830 \\
n=15\end{array}$ \\
\hline
\end{tabular}

${ }^{\text {aSFL }}=$ Sustainable Forest License

${ }^{\mathrm{b}} \mathrm{BA}=$ Basal area

${ }^{\mathrm{c}} \mathrm{AGS}=$ Acceptable growing stock

\section{Damage to residual trees}

Of the 3082 trees inspected for damage, 389 or $12.6 \%$ had evidence of damage that resulted from felling and skidding operations. Only 175 or $5.7 \%$ had wounds that were considered major damage. Full-tree skidding resulted in damage (both major and minor) to $11.1 \pm 1.9 \%$ and TL operations resulted in damage to $14.5 \pm 2.6 \%$ of the total trees sampled (Table 1 ). The rate of tree damage between the FT and TL harvest systems did not differ significantly $(P=0.416)$. Of the trees damaged in the FT operations, only $4.3 \pm 1.0 \%$ had major damage. This low rate of damage did not differ significantly $(P=0.190)$ from the $6.2 \pm 0.9 \%$ of trees with major damage following the TL operation (Table 1, Fig. 3). Although average damage rates were low for both types of harvesting operations, large differences in damage rates were observed among harvest blocks. Major damage in the FT harvest blocks ranged from 2.5\% to $6.9 \%$, while in the TL blocks it ranged from $2.8 \%$ to $9.6 \%$.

The proportion of trees deemed AGS varied among harvest blocks, ranging from $37 \%$ to $98 \%$. Stands with higher proportions of conifer had a greater proportion of stems in the AGS category. Across all harvest blocks, $72 \%$ of the residual stems were deemed AGS. Although major damage to AGS trees did occur, the rate of damage was variable and no significant differences $(P=0.341)$ in damage rate were observed between the FT $(6.8 \pm 2.0 \%)$ and TL $(9.7 \pm 1.9 \%)$ operations (Table 1, Fig. 3). However, the proportion of damage to AGS depends on the ratio of AGS trees to all trees. Thus, a high proportion of AGS damage may, in some cases, be more reflective of limited AGS trees in the stand than actual damage rates.

Historic (collected between 2004 and 2010) exceptions monitoring data shows similar trends of no significant difference $(P=0.589)$ in major damage to total BA. Trees in the 34 FT harvest blocks (18 white pine and 16 hardwood) averaged $7.6 \pm 0.7 \%$ major damage compared to $8.1 \pm 0.6 \%$ for those in TL harvest blocks. Major damage to AGS BA in the FT $(7.3 \pm 0.6 \%)$ harvest blocks also did not differ significantly $(P$ $=0.372)$ from that in the TL $(8.1 \pm 0.5 \%)$ harvest blocks (Table 2, Fig. 3).

\section{Coarse woody debris volumes}

Coarse woody debris volumes in the TL harvesting block ranged from $38.7 \mathrm{~m}^{3} \mathrm{ha}^{-1}$ to $90.8 \mathrm{~m}^{3} \mathrm{ha}^{-1}$, with a mean of $55.4 \pm 5.3 \mathrm{~m}^{3} \mathrm{ha}^{-1}$. These volumes did not differ statistically $(P$ $=0.830$ ) from those in the FT harvest blocks, which ranged from $47.4 \mathrm{~m}^{3} \mathrm{ha}^{-1}$ to $68.7 \mathrm{~m}^{3} \mathrm{ha}^{-1}$, with a mean of $57.2 \pm 3.9 \mathrm{~m}^{3}$ ha $^{-1}$ (Table 1, Fig. 4). The distribution of CWD among decay classes did not differ statistically between harvesting treatments (Fig.5). New CWD in decay class I and II made up $36.9 \%$ and $35.5 \%$ of the total volume in the FT and TL harvest treatments, respectively. Individual CWD diameters increased with increasing decay class whereby CWD in decay 


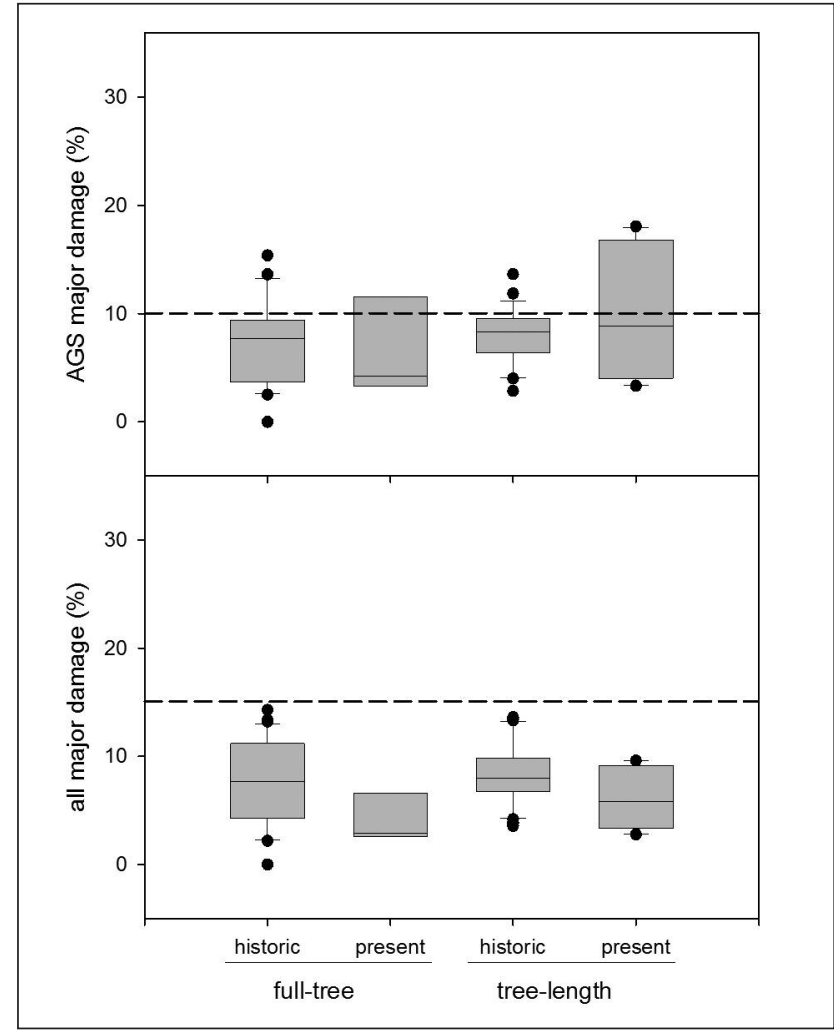

Fig. 3. Box plot of percent major damage to total and acceptable growing stock (AGS) of residual basal area in both recent and historic full-tree and tree-length harvest blocks. Boxes represent the $25^{\text {th }}$ and $75^{\text {th }}$ percentile; bars represent the $10^{\text {th }}$ and $90^{\text {th }}$ percentile. Plots below the $10^{\text {th }}$ percentile and above the $90^{\text {th }}$ percentile of residual basal area are represented by dots. Dashed horizontal lines show the standard for acceptable levels of major damage to both total (15\%) and AGS (10\%) residual basal area.

classes IV and V was significantly larger than that in decay classes I and II (data not shown). No significant difference in piece size was apparent between harvest treatments.

\section{Discussion}

The concern over FT logging in partial harvest systems is that coarse-branched species like most hardwoods and large white pines will result in increased damage to residuals due to wider and longer loads during the skidding phase of harvest operations. Requirements for careful logging practices and maximum damage standards for partial harvesting operations on Crown land in Ontario are in place to help minimize damage to forest stands harvested using shelter wood and selection systems (OMNR 1998a,b). Under these standards, major damage must affect $<15 \%$ of total basal area and $<10 \%$ of AGS basal area. Using the more stringent definition of major damage applied in this study, both FT and TL logging operations were, on average, under the $10 \%$ standard for major damage to AGS basal area (Fig.4). Unfortunately not all of the harvest blocks evaluated were below the $10 \%$ standard. In the current study, two of five (40\%) FT harvest blocks and four of 10 (40\%) TL harvest blocks had excessive damage to AGS stems. The historic exceptions monitoring blocks, for which less stringent definitions of major damage were applied, were also, on average, within the standard for major damage to AGS. Six of the $34(17.6 \%)$ FT blocks matched or exceeded the $10 \%$ major damage to AGS standard compared to three of 25 (12\%) TL harvest blocks. Overall damage levels, however, may be a better reflection of careful logging success since AGS damage levels are highly sensitive to the proportion of AGS trees in a stand. These rates of damage from FT (and TL) operations are comparable to findings by Cline et al. (1991) that average block-level damage frequency was $<10 \%$ during whole-tree $(=$ FT) harvesting in hardwood and mixed forests in the eastern United States. However, examples of damage levels exceeding $30 \%$ as a result of FT harvesting do exist (e.g., Nichols et al. 1994).

The fact that there were no statistical differences in damage between harvest methods suggests that skidding with or without limbs is not a factor in residual tree damage for shelterwood regeneration cuts when careful logging methods are used. The extent of logging damage can be explained by several other factors, but these can vary: density and arrangement of skid trails, proportion of timber harvested, density of residual stems, season of operation, operator experience, and terrain (e.g., Cline et al. 1991, Nichols et al. 1994). All these factors can be controlled with the use of careful logging practices and effective planning and layout of trails and landings. In addition, the regeneration phase of a uniform shelterwood harvest requires that the stand be thinned from below and that the largest and healthiest crowns of desirable species are retained as seed source for natural regeneration. The trees to be removed are typically smaller-diameter trees with relatively small and flexible tops and branches. It is likely that the additional material in FT logging was not too much greater in width and length than the TL system and that the extra material was thin and flexible enough not to damage residual trees excessively if contact during skidding were to occur.

Aside from concerns related to potential damage to residual trees during FT harvest, concerns have been raised about potential effects on nutrient balances and recruitment of CWD, regardless of silvicultural system (Berch et al. 2011, Puddister et al. 2011). Retention of coarse woody material is an important part of sustaining forest productivity and biodiversity (Spies 1998, Shields et al. 2007, Vanderwel et al. 2009, OMNR 2010), though quantities vary considerably (Fig.. 4). Published volumes for CWD in northern hardwood and mixed forests of eastern North America show values ranging from $10.8 \mathrm{~m}^{3} \mathrm{ha}^{-1}$ to $136.7 \mathrm{~m}^{3} \mathrm{ha}^{-1}$, and averaging $60.5 \mathrm{~m}^{3} \mathrm{ha}^{-}$ ${ }^{1}$ (Fig. 4). Typically, mature second-growth and old-growth forests had greater volumes of CWD than managed forests (Fig. 4). The CWD volumes measured in our study ranged from $36.3 \mathrm{~m}^{3} \mathrm{ha}^{-1}$ to $90.8 \mathrm{~m}^{3} \mathrm{ha}^{-1}$ and were comparable to the range of values for managed and unmanaged forests elsewhere (Fig. 4). Moreover, the FT and TL harvest systems did not differ in terms of total volume or the distribution of that volume across decay classes (Fig. 5). The majority of the postharvest volumes of CWD in both FT and TL systems were is the later decay stages and likely pre-dated the harvest (Fig. 5). Addition of new CWD, those in decay class I and II were low in both systems and were not significantly different between FT and TL harvests. Although FT harvesting will likely result in lower residual "slash" volumes in the short term, we do not necessarily expect to see reductions in CWD, i.e., pieces larger 


\begin{tabular}{|c|c|c|c|c|c|c|c|c|}
\hline \multirow[b]{2}{*}{ Block name } & \multirow[b]{2}{*}{ SFL } & \multirow[b]{2}{*}{ Forest type } & \multirow[b]{2}{*}{$\begin{array}{l}\text { Number } \\
\text { of plots }\end{array}$} & \multirow[b]{2}{*}{$\begin{array}{l}\text { Total } \mathbf{B A}^{\mathrm{a}} \\
\left(\mathbf{m}^{2} \mathbf{h a}^{-1}\right)\end{array}$} & \multirow{2}{*}{$\begin{array}{c}\text { Total AGS } \\
\text { BA }\left(\mathbf{m}^{2} \mathbf{h a}^{-1}\right)\end{array}$} & \multirow[b]{2}{*}{$\begin{array}{l}\text { Total BA } \\
\left(\mathbf{m}^{2} \mathbf{h a}^{-1}\right)\end{array}$} & \multicolumn{2}{|c|}{ Damage (\% BA) } \\
\hline & & & & & & & Major all & Major AGS ${ }^{b}$ \\
\hline \multicolumn{9}{|l|}{ Full-tree } \\
\hline Cloutier 126 FT & Nipissing & White pine & 5 & 8.0 & 7.2 & 8.0 & 0.0 & 0.0 \\
\hline Cloutier $129 \mathrm{FT}$ & Nipissing & White pine & 66 & 10.0 & 9.0 & 10.0 & 4.0 & 3.0 \\
\hline Grant 14 & Nipissing & White pine & 37 & 11.9 & 9.1 & 11.9 & 7.7 & 7.7 \\
\hline Grant 17 & Nipissing & White pine & 27 & 6.7 & 5.6 & 6.7 & 2.2 & 2.6 \\
\hline Mad 123 FT & Nipissing & White pine & 95 & 12.1 & 10.5 & 12.1 & 6.8 & 6.8 \\
\hline N’bisissing 34 & Nipissing & White pine & 17 & 11.3 & 8.2 & 11.3 & 9.4 & 12.9 \\
\hline Tem 107A & Nipissing & White pine & 46 & 11.8 & 10.3 & 11.8 & 2.6 & 2.5 \\
\hline Tem 107B & Nipissing & White pine & 55 & 10.2 & 8.6 & 10.2 & 3.9 & 3.8 \\
\hline 108 & Northshore & White pine & 60 & 7.8 & 6.3 & 7.8 & 7.2 & 7.4 \\
\hline 54 PW & Northshore & White pine & 10 & 7.8 & 6.4 & 7.8 & 2.6 & 3.1 \\
\hline 72 PWUS & Northshore & White pine & 10 & 14.2 & 13.4 & 14.2 & 7.0 & 7.5 \\
\hline 551 & Northshore & White pine & 10 & 12.2 & 10.6 & 12.2 & 11.5 & 9.4 \\
\hline 333 & Northshore & White pine & 10 & 10.8 & 10.0 & 10.8 & 9.3 & 10 \\
\hline $459 \& 385$ & Northshore & White pine & 10 & 9.8 & 9.2 & 9.8 & 6.1 & 6.5 \\
\hline 182 & Northshore & White pine & 30 & 7.8 & 6.3 & 7.8 & 9.4 & 9.5 \\
\hline 72 PW MIX & Northshore & White pine & 7 & 12.3 & 9.4 & 12.3 & 2.3 & 3.0 \\
\hline $416 \mathrm{~B}$ & Northshore & White pine & 5 & 12.0 & 9.6 & 12.0 & 13.3 & 8.3 \\
\hline 416 & Northshore & White pine & 7 & 10.9 & 9.7 & 10.9 & 13.2 & 8.8 \\
\hline Behnke 67 & Nipissing & Hardwood & 11 & 16.7 & 8.7 & 16.7 & 7.6 & 12.5 \\
\hline 175 & Northshore & Hardwood & 30 & 7.9 & 5.1 & 7.9 & 6.7 & 5.2 \\
\hline 179 & Northshore & Hardwood & 30 & 8.4 & 5.7 & 8.4 & 4.8 & 7.1 \\
\hline 302 & Northshore & Hardwood & 43 & 9.5 & 7.1 & 9.5 & 4.4 & 3.3 \\
\hline 600 & Northshore & Hardwood & 30 & 4.7 & 1.7 & 4.7 & 14.3 & 15.4 \\
\hline 54 HWD & Northshore & Hardwood & 10 & 10.6 & 4.4 & 10.6 & 9.4 & 13.6 \\
\hline 560 & Northshore & Hardwood & 10 & 10.4 & 4.6 & 10.4 & 0.0 & 0.0 \\
\hline 828,2009 & Northshore & Hardwood & 5 & 13.6 & 5.2 & 13.6 & 8.8 & 7.7 \\
\hline 828, 2008_1 & Northshore & Hardwood & 10 & 11.4 & 6.6 & 11.4 & 10.5 & 9.1 \\
\hline $828,2008 \_2$ & Northshore & Hardwood & 10 & 15.4 & 7.8 & 15.4 & 11.7 & 7.7 \\
\hline 822 & Northshore & Hardwood & 10 & 15.0 & 7.6 & 15.0 & 12.0 & 7.9 \\
\hline 857_1 & Northshore & Hardwood & 10 & 14.4 & 8.2 & 14.4 & 11.1 & 9.8 \\
\hline $857-2$ & Northshore & Hardwood & 10 & 9.4 & 5.0 & 9.4 & 12.8 & 8 \\
\hline $885^{-}$ & Northshore & Hardwood & 10 & 9.0 & 5.2 & 9.0 & 8.9 & 7.7 \\
\hline 409_1 & Northshore & Hardwood & 10 & 10.4 & 8.8 & 10.4 & 5.8 & 6.8 \\
\hline 409_2 & Northshore & Hardwood & 10 & 8.2 & 4.4 & 8.2 & 12.2 & 13.6 \\
\hline Mean \pm SE & & & & $10.7 \pm 0.5$ & $7.5 \pm 0.4$ & $10.7 \pm 0.5$ & $7.6 \pm 0.7$ & $7.3 \pm 0.6$ \\
\hline \multicolumn{9}{|l|}{ Tree-length } \\
\hline Goulard $10 \mathrm{TL}$ & Nipissing & White pine & 53 & 9.9 & 7.5 & 9.9 & 4.2 & 5.6 \\
\hline Tem 105 TL & Nipissing & White pine & 20 & 11.3 & 9.5 & 11.3 & 9.7 & 9.5 \\
\hline Cloutier $126 \mathrm{TL}$ & Nipissing & White pine & 6 & 9.3 & 8.0 & 9.3 & 3.6 & 4.2 \\
\hline Cloutier $129 \mathrm{TL}$ & Nipissing & White pine & 22 & 10.3 & 8.9 & 10.3 & 7.1 & 7.1 \\
\hline Mad 123 TL & Nipissing & White pine & 36 & 11.6 & 9.7 & 11.6 & 4.3 & 2.9 \\
\hline 824 & Northshore & White pine & 12 & 10.2 & 9.8 & 10.2 & 13.1 & 11.9 \\
\hline 841 & Northshore & White pine & 10 & 11.6 & 8.6 & 11.6 & 6.9 & 9.3 \\
\hline 880 & Northshore & White pine & 7 & 12.0 & 12.0 & 12.0 & 4.8 & 4.8 \\
\hline 884 & Northshore & White pine & 22 & 12.2 & 11.5 & 12.2 & 6.7 & 5.5 \\
\hline 885 & Northshore & White pine & 10 & 13.2 & 12.2 & 13.2 & 7.6 & 8.2 \\
\hline 898 & Northshore & White pine & 44 & 13.0 & 12.6 & 13.0 & 9.8 & 9.0 \\
\hline 902 & Northshore & White pine & 10 & 14.8 & 12.2 & 14.8 & 13.5 & 9.8 \\
\hline 5420 & Northshore & White pine & 5 & 10.4 & 10.0 & 10.4 & 3.8 & 4.0 \\
\hline 5930 & Northshore & White pine & 10 & 10.0 & 9.0 & 10.0 & 10.0 & 8.9 \\
\hline 6731 & Northshore & White pine & 10 & 8.6 & 7.0 & 8.6 & 7.0 & 8.6 \\
\hline 6847 & Northshore & White pine & 10 & 11.0 & 11.0 & 11.0 & 9.1 & 9.1 \\
\hline 7151 & Northshore & White pine & 10 & 10.8 & 10.4 & 10.8 & 9.3 & 9.6 \\
\hline 9638 & Northshore & White pine & 10 & 9.0 & 8.8 & 9.0 & 13.3 & 13.6 \\
\hline 1416,1468 & Northshore & White pine & 10 & 10.8 & 9.6 & 10.8 & 9.3 & 8.3 \\
\hline 43,161 & Northshore & White pine & 10 & 10.8 & 10.0 & 10.8 & 9.3 & 10.0 \\
\hline 5420,5930 & Northshore & White pine & 10 & 10.8 & 10.0 & 10.8 & 7.4 & 8.0 \\
\hline 9734-A & Northshore & White pine & 7 & 8.3 & 8.0 & 8.3 & 10.3 & 10.7 \\
\hline 6109 & Northshore & Hardwood & 10 & 9.4 & 7.4 & 9.4 & 6.4 & 8.1 \\
\hline 7819 & Northshore & Hardwood & 27 & 8.7 & 6.1 & 8.7 & 10.2 & 7.3 \\
\hline 228 & Nipissing & Hardwood & 36 & 10.6 & 4 & 10.6 & 6.8 & 8.3 \\
\hline Mean \pm SE & & & & $10.7 \pm 0.3$ & $9.4 \pm 0.4$ & $10.7 \pm 0.3$ & $8.1 \pm 0.6$ & $8.1 \pm 0.5$ \\
\hline \multirow{3}{*}{\multicolumn{4}{|c|}{ ANOVA }} & & & & & \\
\hline & & & & $P=0.902$ & $P=0.003$ & $P=0.902$ & $P=0.589$ & $P=0.372$ \\
\hline & & & & $n=59$ & $n=59$ & $n=59$ & $n=59$ & $n=59$ \\
\hline
\end{tabular}

\footnotetext{
${ }^{\mathrm{a}} \mathrm{BA}=$ Basal area; ${ }^{\mathrm{b}} \mathrm{AGS}=$ Acceptable growing stock
} 


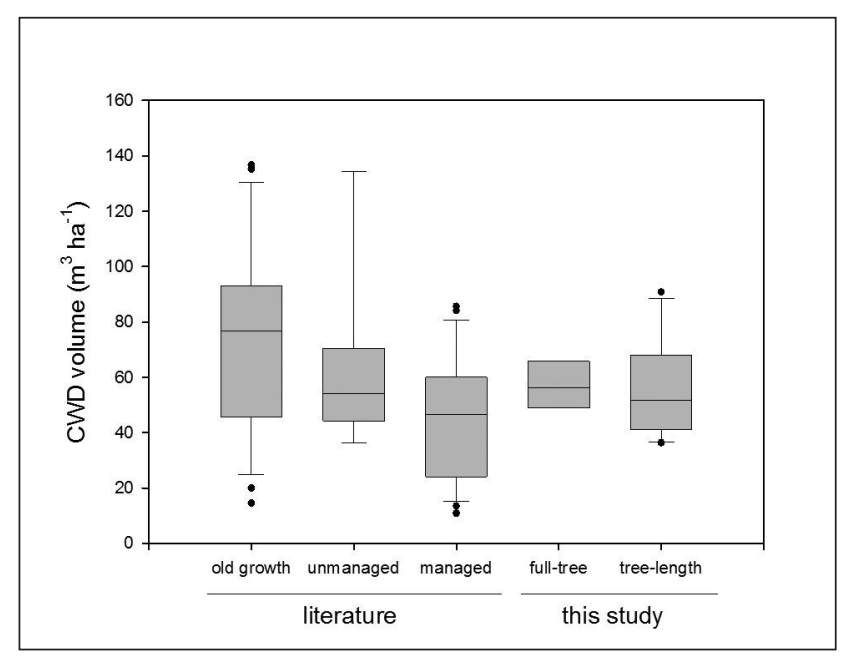

Fig. 4. Comparison of coarse woody debris (CWD) volumes, from old growth, unmanaged second growth and managed forest, reported in the literature, to those from full-tree and tree-length harvest blocks in this study. Boxes represent the $25^{\text {th }}$ and $75^{\text {th }}$ percentile; bars represent the $10^{\text {th }}$ and $90^{\text {th }}$ percentile. Data below the $10^{\text {th }}$ percentile and above the $90^{\text {th }}$ percentile of CWD volumes appear as dots.

than $10 \mathrm{~cm}$ in diameter. Residual biofibre (tree tops, cull trees, unmerchantable trees, and salvaged trees) from partial harvests tends to be tops, branches, and unmerchantable species left post-harvest. The difference in biofibre loads between the two harvest systems is therefore primarily due to the removal of tops and branches during FT harvesting.

In Ontario, those implementing current TL harvest systems are required to adhere to the utilization standards set out in the provincial scaling manual (OMNR 2007) whereby conifers, poplar, and birch should be topped to a diameter of $14 \mathrm{~cm}$ and other hardwoods should be topped at $18 \mathrm{~cm}$. In many operations in the GLSL, utilization standards for top diameter are already being exceeded through the recovery of large branches and additional non-merchantable top material that is of sufficient size for use as fuelwood or pulp. For the most part, the tops and branches are smaller in diameter than the criteria used to define CWD and are not captured in CWD surveys. However, CWD loads are dynamic, current volumes are a reflection of past disturbance processes, and future volumes will depend not only on rates of depletion and decay but also on the rate of input from residual standing trees. Direction from the Forest Biofibre - Allocation and Use (OMNR 2008) policy states that available material for harvest includes only "tree tops, cull trees or portions of trees, individual and stands of unmerchantable and unmarketable trees, and trees that may be salvaged as a result of a natural disturbance", and that stumps, below-ground biomass, and CWD must be retained on site (OMNR 2010). Furthermore, current provincial guidelines for the retention of standing trees state that at least 25 trees per hectare be retained in all harvested stands, regardless of silvicultural system (OMNR 2010). These residual trees are meant to maintain structural diversity at the stand scale and provide habitat and future CWD as well as seed sources for natural regeneration into the future. The so-called "wildlife trees" can include any combination of standing healthy, dead, or dying trees, and should include

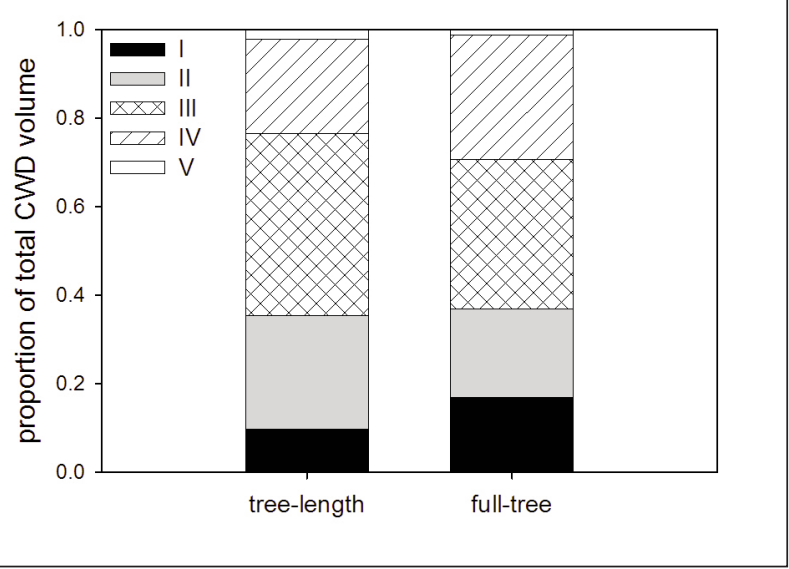

Fig. 5. Proportion of total coarse woody debris volume, by decay class for full-tree and tree-length harvest blocks on 10 sites in central Ontario. Decay class I is freshly dead with branches attached and intact bark and wood; II has intact to partly decaying wood with bark intact to partly missing; III is generally partly decayed with traces of bark; IV is well decayed with bark usually absent and branch stubs will pull out; $V$ is highly decayed with no bark and branch stubs easily pull out (Maser et al.1979).

trees with cavities, mast producers, scattered conifers in hardwood stands, and veteran trees. Following these practices will help to ensure that woody material remaining on harvested sites is comparable to what would occur in natural stands.

\section{Management implications}

Based on our findings, FT harvesting can be done in such a way as to maintain the stand within acceptable damage levels; however, this management approach may not be appropriate in all cases. During the shelterwood regeneration cut stage that we studied little or no regeneration is typically present. The objective at this stage of management is to create a partially shaded understory condition and remove competition to facilitate establishment of a new cohort. Mineral soil exposure may also be desired to establish some species from seed, e.g., white pine and yellow birch (OMNR 1998a,b). Such conditions are created by "thinning from below", removing small suppressed trees and some dominant or co-dominant trees, but mainly those with smaller crowns. Spacing among residual trees also needs to be fairly wide ( $8 \mathrm{~m}$ to $14 \mathrm{~m}$ depending on crown closure targets and crown geometry). For these reasons, FT harvesting is possible without causing excessive damage, and helps create favourable ("clean") conditions for establishing a new cohort of desirable regeneration. Other stages of management and silvicultural systems, however, present additional challenges. At the preparatory cut stage of shelterwood management tree spacing is much tighter, and careful extraction of full trees is difficult. At the removal cut stage, the added risk of damage to established regeneration results from skidding tree tops and limbs; machine traffic can kill saplings and reduce seedling regeneration (Nichols et al. 1994). The selection system has similar challenges with close spacing of residual trees and the need to protect abundant seedlings and saplings. Therefore, while FT harvesting is advantageous for the shelterwood regeneration cut stage, it is 
probably not appropriate for other stages of shelterwood management nor for selection harvesting.

While our results show that damage levels from FT harvesting are similar to those for TL harvesting, excessive damage can occur regardless of logging method, if harvesting is not done carefully. The skill and care of loggers and effective planning of extraction trails and landings are paramount. Extension activities designed to transfer knowledge gained from the operational best management practices developed during initial FT harvest trials may assist in minimizing damage in future FT harvesting operations.

\section{Acknowledgements}

We thank Mike Brienesse and Joe Churcher from MNR's Forests Branch for providing additional funding, helpful suggestions, and constructive criticism on the manuscript. We also acknowledge the hard work and dedication of the field support staff: Michelle Bowman, Lia Fricano, and Jay Kerr. Thanks also to MNR staff in North Bay district (Guylaine Thauvette) as well as SFL staff from the Nipissing Forest (Mark Lockhart and Ric Hansel), Northshore Forest (Norm Iles and Doug Peerla), and the French-Severn Forest (Barry Davidson and Tom Bryson) for providing harvest block information, historic data, and logistical support. Special thanks to Marc Bouthillier and Tembec, Inc. for their contributions of data and logistical support to this study as well as the greater GLSL biomass impacts and opportunities project. Finally, we thank Brian Batchelor, Mike Brienesse, Guylaine Thauvette, Norm Iles and Lisa Buse for their comments on and editorial improvements to this manuscript.

\section{References}

Angers, V.A., C. Messier, M. Beaudet and A. Leduc. 2005. Comparing composition and structure in old-growth and harvested (selection and diameter-limit cuts) northern hardwood stands in Quebec. Forest Ecology and Management 217(2-3): 275-293.

Bedard, S. and Z. Majcen. 2001. Ten-year response of sugar maple-yellow birch-beech stands to selection cutting in Quebec. Northern Journal of Applied Forestry 18(4): 119-126.

Berch, S., D. Morris and J. Malcolm. 2011. Intensive forest biomass harvesting and biodiversity in Canada: A summary of relevant issues. The Forestry Chronicle 87(04): 478-487.

Bolton, N.W. and A.W. D'Amato. 2011. Regeneration responses to gap size and coarse woody debris within natural disturbance-based silvicultural systems in northeastern Minnesota, USA. Forest Ecology and Management 262(7): 1215-1222.

Caspersen, J.P. 2006. Elevated mortality of residual trees following single-tree felling in northern hardwood forests. Canadian Journal of Forest Research 36(5): 1255-1265.

Cline, M.L., B.F. Hoffman, M. Cyr and W. Bragg. 1991. Stand damage following whole-tree partial cutting in northern forests. Northern Journal of Applied Forestry 8(2): 72-76.

D'Amato A.W., D.A. Orwig and D.R. Foster. 2008. The influence of successional processes and disturbance on the structure of Tsuga canadensis forests. Ecological Applications 18(5): 1182-1199.

Doyon, F., D. Gagnon and J.F. Giroux. 2005. Effects of strip and single-tree selection cutting on birds and their habitat in a Southwestern Quebec northern hardwood forest. Forest Ecology and Management 209(1-2): 101-115.

Duckert, D.R. and D.M. Morris. 2008. Soil Quality Monitoring of Shallow Soil Ecosites in Northwestern Ontario: A Five Year PostHarvest Assessment of Regeneration and Soil Quality. Unpublished CNFER Report.
Fajvan, M.A., K.E. Knipling and B.D. Tift. 2002. Damage to Appalachian hardwoods from diameter-limit harvesting and shelterwood establishment cutting. Northern Journal of Applied Forestry 19(2): 80-87.

Fleming, R. 2011. CFS-OMNR-NSFC Bioenergy Research Initiatives in Ontario's Boreal Forest. Unpublished Report.

Forget, E., P. Nolet, F. Doyon, S. Delagrange and Y. Jardon. 2007. Ten-year response of northern hardwood stands to commercial selection cutting in southern Quebec, Canada. Forest Ecology and Management 242(2-3): 764-775.

Forrester, J.A. and J.R. Runkle. 2000. Mortality and Replacement Patterns of an Old-Growth Acer-Fagus Woods in the Holden Arboretum, Northeastern Ohio. American Midland Naturalist 144(2): 227-242.

Goebel, P.C. and D.M. Hix. 1996. Development of mixed-oak forests in southeastern Ohio: A comparison of second-growth and old-growth forests. Forest Ecology and Management 84(1-3): 1-21. Goodburn, J.M. and C.G. Lorimer. 1998. Cavity trees and coarse woody debris in old-growth and managed northern hardwood forests in Wisconsin and Michigan. Canadian Journal of Forest Research 28(3): 427-438.

Hale, C.M., J. Pastor and K.A. Rusterholz. 1999. Comparison of structural and compositional characteristics in old-growth and mature, managed hardwood forests of Minnesota, USA. Canadian Journal of Forest Research 29(10): 1479-1489.

Hardt, R.A. and W.T. Swank. 1997. A comparison of structural and compositional characteristics of southern Appalachian young second-growth, maturing second-growth, and old-growth stands. Natural Areas Journal 17(1): 42-52.

Hornbeck, J.W., C.T. Smith, Q.W. Martin, L.M. Tritton and R.S. Pierce. 1990. Effects of intensive harvesting on nutrient capitals of 3 forest types in New England. Forest Ecology and Management 30(1-4): 55-64.

Hura, C.E. and T.R. Crow. 2004. Woody debris as a component of ecological diversity in thinned and unthinned northern hardwood forests. Natural Areas Journal 24(1): 57-64.

Jackson, S.M., F. Pinto, J.R. Malcolm and E.R. Wilson. 2000. A comparison of pre-European settlement (1857) and current (1981-1995) forest composition in central Ontario. Canadian Journal of Forest Research 30(4): 605-612.

Jenkins, M.A., C.R. Webster, G.R. Parker and M.A. Spetich. 2004. Coarse woody debris in managed Central Hardwood Forests of Indiana, USA. Forest Science 50(6): 781-792.

Jones, T.A. and S.C. Thomas. 2004. The time course of diameter increment responses to selection harvests in Acer saccharum. Canadian Journal of Forest Research 34(7): 1525-1533.

Keeton, W.S. 2006. Managing for late-successional/old-growth characteristics in northern hardwood-conifer forests. Forest Ecology and Management 235(1-3): 129-142.

Kelly, R.S. 1983. Stand damage from whole-tree harvesting in Vermont hardwoods. Journal of Forestry 81(2): 95-96.

Marshall, P.L., G. Davis, and V.M. LeMay. 2000. Using line intersect sampling for coarse woody debris. Forest Resources Management Department. TR-003. Available at http://www.for.gov.bc.ca/ RCO/Research/CWD/tr003.pdf.

Maser, C., R.G. Anderson, K.J. Cromack, J.T. Williams and R.E. Martin. 1979. Dead and down woody material. In J.W. Thomas (ed.). Wildlife Habitats in Managed Forests - the Blue Mountains of Oregon and Washington. pp. 78-95. USDA Forest Service Agricultural Handbook 553. Washington DC.

McGee, G.G., D.J. Leopold and R.D. Nyland. 1999. Structural characteristics of old-growth, maturing, and partially cut northern hardwood forests. Ecological Applications 9(4): 1316-1329.

Morris, D.M. 2009. Changes in DOC and DON fluxes in response to harvest intensity of black-spruce-dominated forest ecosystems in northwestern Ontario. Canadian Journal of Soil Science 89(1): $67-79$. 
Morris, D.M. and D.R. Duckert. 1999. Studying the impacts of harvest intensity on site productivity of Ontario's black spruce ecosystems. The Forestry Chronicle 75(3): 439-445.

Muller, R.N. and L. Yan. 1991. Coarse woody debris in and oldgrowth deciduous forest on the Cumberland plateau, southeastern Kentucky. Canadian Journal of Forest Research 21(11): 1567-1572. Neuendorff, J.K., L.M. Nagel, C.R. Webster and M.K. Janowiak. 2007. Stand structure and composition in a northern hardwood forest after 40 years of single-tree selection. Northern Journal of Applied Forestry 24(3): 197-202.

Nichols, M.T., R.C. Lemin Jr. and W.D. Ostrofsky. 1994. The impact of two harvesting systems on residual stems in a partially cut stand of northern hardwoods. Canadian Journal of Forest Research 24(2): 350-357.

[OMNR] Ontario Ministry of Natural Resources. 1998a. A silvicultural guide for the tolerant hardwood forest in Ontario. Ontario Ministry of Natural Resources, Toronto, ON. 500 p.

. 1998b. A silvicultural guide for the Great Lakes-St. Lawrence conifer forest in Ontario. Ontario Ministry of Natural Resources, Toronto, ON. 424 p.

. 2004. Ontario tree marking guide, Version 1.1. Ontario Ministry of Natural Resources, Toronto, ON. 252 p.

- 2007. Scaling manual. Ontario Ministry of Natural Resources. Toronto, ON. Available at http://www.web2.mnr.gov. on.ca/mnr/forests/forestdoc/reg_manuals/manuals/scaling/file_one .pdf [Accessed February 29, 2012].

. 2008. Forest biofibre - allocation and use. Ontario Ministry of Natural Resources, Forest Management Branch, Toronto, ON. For. Manage. Direct. FOR 0302 01. 5 p. Available at http://www.mnr.gov. on.ca/stdprodconsume/groups/lr/@mnr/@forests/documents/document/275477.pdf [Accessed February 29, 2012].

2010. Forest management guide for conserving biodiversity at the stand and site scales. Ontario Ministry of Natural Resources. Toronto, ON. 211 p.

Orwig, D.A., C.V. Cogbill, D.R. Foster and J.F. O'Keefe. 2001. Variations in old-growth structure and definitions: Forest dynamics on Wachusett Mountain, Massachusetts. Ecological Applications 11(2): 437-452.

Puddister, D. et al. 2011. Opportunities and challenges for Ontario's forest bioeconomy. The Forestry Chronicle 87(4): 468-477.

Rice, J.A. 1994. Logging damage: the problems and practical solutions. Ontario Ministry of Natural Resources, Ontario Forest Research Institute, Sault Ste. Marie, ON. Forest Research Information Paper No. 117.

Roovers, L.M. and S.R. Shifley. 1997. Composition and dynamics of Spitler Woods, an old-growth remnant forest in Illinois (USA). Natural Areas Journal 17(3): 219-232.

Rubino, D.L. and B.C. McCarthy. 2003. Evaluation of coarse woody debris and forest vegetation across topographic gradients in a southern Ohio forest. Forest Ecology and Management 183(1-3): 221-238.
Schwartz, J.W., L.M. Nagel and C.R. Webster. 2005. Effects of uneven-aged management on diameter distribution and species composition of northern hardwoods in upper Michigan. Forest Ecology and Management 211(3): 356-370.

Shields, J.M., C.R. Webster and L.M. Nagel. 2007. Factors influencing tree species diversity and Betula alleghaniensis establishment in silvicultural openings. Forestry 80(3): 293-307.

Spetich, M.A., S.R. Shifley and G.R. Parker. 1999. Regional distribution and dynamics of coarse woody debris in Midwestern oldgrowth forests. Forest Science 45(2): 302-313.

Spies, T.A. 1998. Forest structure: a key to the ecosystem. Northwest Science 72(SI-2): 34-39.

Statutes of Ontario. 1995. Crown Forest Sustainability Act, revised. R.S.O. 1998. Chapter 25 and Ontario Regulation 167/95.

Stewart, B.J., P.D. Neily, E.J. Quigley, A.P. Duke and L.K. Benjamin. 2003. Selected Nova Scotia old-growth forests: Age, ecology, structure, scoring. Forestry Chronicle 79(3): 632-644.

Tenhagen, M.D., J.K. Jeglum, S. Ran and N.W. Foster. 1996. Effects of a range of biomass removals on long-term productivity of jack pine ecosystems: Establishment report. Natural Resources Canada, Canadian Forest Service, Great Lakes Forestry Centre, Sault Ste. Marie, ON. Inf. Rep. O-X-454. 13 p. + appendices.

Tyrell, L.E. and T.R. Crow. 1994. Dynamics of dead wood in oldgrowth hemlock-hardwood forests of northern Wisconsin and northern Michigan. Canadian Journal of Forest Research 24(8): 1672-1683.

Vanderwel, M.C., S.C. Mills and J.R. Malcolm. 2009. Effects of partial harvesting on vertebrate species associated with late-successional forests in Ontario's boreal region. The Forestry Chronicle 85(1): 91-104.

Vanderwel, M.C., H.C. Thorpe, J.L. Shuter, J.P. Caspersen and S.C. Thomas. 2008. Contrasting downed woody debris dynamics in managed and unmanaged northern hardwood stands. Canadian Journal of Forest Research 38(11): 2850-2861.

Vasiliauskas, R. 2001. Damage to trees due to forestry operations and its pathological significance in temperate forests: a literature review. Forestry 74(4): 319-336.

Webster, C.R. and M.A. Jenkins. 2005. Coarse woody debris dynamics in the southern Appalachians as affected by topographic position and anthropogenic disturbance history. Forest Ecology and Management 217(2-3): 319-330.

Webster, C.R. and N.R. Jensen. 2007. A shift in the gap dynamics of Betula alleghaniensis in response to single-tree selection. Canadian Journal of Forest Research 37(3): 682-689.

Ziegler, S.S. 2000. A comparison of structural characteristics between old-growth and postfire second-growth hemlock-hardwood forests in Adirondack Park, New York, NY. Global Ecology and Biogeography 9(5): 373-389. 
Appendix A. List of literature sources and CWD volumes used in Fig. 5: comparing management effects on CWD volumes.

\begin{tabular}{|c|c|c|c|c|}
\hline Source & Location & Forest type & $\begin{array}{l}\text { Management approach/ } \\
\text { stand type }\end{array}$ & $\begin{array}{l}\text { Volume } \\
\left(\mathrm{m}^{3} \mathrm{ha}^{-1}\right)\end{array}$ \\
\hline Angers et al. 2005 & Quebec & Northern hardwood & Selection & 72.7 \\
\hline Angers et al. 2005 & Quebec & Northern hardwood & Diameter limit & 41.6 \\
\hline Angers et al. 2005 & Quebec & Northern hardwood & Old growth & 78.4 \\
\hline Bolton 2011 & Minnesota & Hardwood & Unmanaged second growth & 77.8 \\
\hline D’Amato et al. 2008 & Massachusetts & Hemlock-hardwood & Second growth & 33.2 \\
\hline D'Amato et al. 2008 & Massachusetts & Hemlock-hardwood & Old growth & 135.2 \\
\hline Doyon et al. 2005 & Quebec & Northern hardwood & Strip cut & 46.8 \\
\hline Doyon et al. 2005 & Quebec & Northern hardwood & Selection & 60.7 \\
\hline Doyon et al. 2005 & Quebec & Northern hardwood & Unmanaged second growth & 36.2 \\
\hline Forrester and Runkle 2000 & Ohio & Hardwood & Old growth & 80.2 \\
\hline Goebel and Hix 1996 & Ohio & Northern hardwood & Second growth & 13.5 \\
\hline Goebel and Hix 1996 & Ohio & Northern hardwood & Old growth & 29.8 \\
\hline Goodburn and Lorimer 1998 & Wisconsin/Michigan & Northern hardwood & Selection & 61.3 \\
\hline Goodburn and Lorimer 1998 & Wisconsin/Michigan & Northern hardwood & Even-aged & 24.6 \\
\hline Goodburn and Lorimer 1998 & Wisconsin/Michigan & Hemlock-hardwood & Selection & 56.0 \\
\hline Goodburn and Lorimer 1998 & Wisconsin/Michigan & Northern hardwood & Old growth & 102.2 \\
\hline Goodburn and Lorimer 1998 & Wisconsin/Michigan & Hemlock-hardwood & Old growth & 93.9 \\
\hline Hale et al. 1999 & Minnesota & Northern hardwood & Old growth & 88.0 \\
\hline Hale et al. 1999 & Minnesota & Oak hardwood & Old growth & 75.0 \\
\hline Hale et al. 1999 & Minnesota & Northern hardwood & Mature second growth & 49.0 \\
\hline Hale et al. 1999 & Minnesota & Oak hardwood & Mature second growth & 46.0 \\
\hline Hardt and Swank 1997 & North Carolina & Northern hardwood & Old growth & 86.0 \\
\hline Hura and Crow 2004 & Michigan & Northern hardwood & Second growth & 46.5 \\
\hline Hura and Crow 2004 & Michigan & Northern hardwood & Thinned uneven-aged & 84.1 \\
\hline Hura and Crow 2004 & Michigan & Northern hardwood & Thinned even-aged & 47.4 \\
\hline Hura and Crow 2004 & Michigan & Northern hardwood & Old growth & 120.5 \\
\hline Jenkins et al. 2004 & Indiana & Hardwood & Managed & 22.4 \\
\hline Jenkins et al. 2004 & Indiana & Hardwood & Managed & 19.0 \\
\hline Jenkins et al. 2004 & Indiana & Hardwood & Managed & 10.8 \\
\hline Keeton 2006 & Vermont & Northern hardwood & Selection & 49.0 \\
\hline McGee et al. 1999 & New York & Northern hardwood & Partial cut & 59.9 \\
\hline McGee et al. 1999 & New York & Northern hardwood & Maturing even aged & 59.0 \\
\hline McGee et al. 1999 & New York & Northern hardwood & Old growth & 136.7 \\
\hline Muller and Yan 1991 & Kentucky & Oak hardwood & Old growth & 47.8 \\
\hline Orwig et al. 2001 & Massachusetts & Mixed hardwood & Old growth & 34.2 \\
\hline Orwig et al. 2001 & Massachusetts & Mixed hardwood & Old growth & 14.5 \\
\hline Orwig et al. 2001 & Massachusetts & Mixed hardwood & Old growth & 19.9 \\
\hline Orwig et al. 2001 & Massachusetts & Mixed hardwood & Old growth & 32.2 \\
\hline Roovers and Shifley 1997 & Illinois & Oak hardwood & Old growth & 81.2 \\
\hline Rubino and McCarthy 2003 & Ohio & Oak hardwood & Unmanaged second growth & 42.5 \\
\hline Spetich et al. 1999 & Midwest, USA & Hardwood & Second growth & 20.0 \\
\hline Spetich et al. 1999 & Midwest, USA & Hardwood & Old growth & 60.0 \\
\hline Stewart et al. 2003 & Nova Scotia & Mixed hardwood & Old growth & 58.0 \\
\hline Stewart et al. 2003 & Nova Scotia & Mixed hardwood & Old growth & 45.0 \\
\hline Stewart et al. 2003 & Nova Scotia & Mixed hardwood & Old growth & 71.0 \\
\hline Stewart et al. 2003 & Nova Scotia & Mixed hardwood & Old growth & 91.0 \\
\hline Tyrell and Crow 1994 & Michigan $\backslash$ Wisconsin & Hemlock-hardwood & Old growth & 54.8 \\
\hline Tyrell and Crow1994 & Michigan $\backslash$ Wisconsin & Hemlock-hardwood & Unmanaged second growth & 54.0 \\
\hline Vanderwel et al. 2008 & Ontario & Northern hardwood & Selection & 45.5 \\
\hline Vanderwel et al. 2008 & Ontario & Northern hardwood & Selection & 43.6 \\
\hline Vanderwel et al. 2008 & New York & Northern hardwood & Unmanaged second growth & 58.5 \\
\hline Webster and Jenkins 2005 & Kentucky & Mixed hardwood & Managed & 85.6 \\
\hline Webster and Jenkins 2005 & Kentucky & Mixed hardwood & Unmanaged second growth & 134.3 \\
\hline Ziegler 2000 & New York & Hemlock-hardwood & Old growth & 126.0 \\
\hline Ziegler 2000 & New York & Hemlock-hardwood & Unmanaged second growth & 63.0 \\
\hline
\end{tabular}

